\title{
A tribute to Boenigk (1978): The fluvial development of the Lower Rhine Basin during the late Tertiary and early Quaternary
}

Philip L. Gibbard

Scott Polar Research Institute, University of Cambridge, Lensfield Road, Cambridge CB2 1ER, UK

Correspondence: $\quad$ Philip L. Gibbard (plg1@cam.ac.uk)

Relevant dates: $\quad$ Received: 15 May 2021 - Revised: 27 June 2021 - Accepted: 30 October 2021 Published: 17 December 2021

How to cite: Gibbard, P. L.: A tribute to Boenigk (1978): The fluvial development of the Lower Rhine Basin during the late Tertiary and early Quaternary, E\&G Quaternary Sci. J., 70, 251-255, https://doi.org/10.5194/egqsj-70-251-2021, 2021.

Special issue statement. This article is part of a special issue published on the occasion of the 70th anniversary of $E \& G$ Quaternary Science Journal (EGQSJ). The special issue celebrates the journal's notable contribution to Quaternary research by revisiting selected milestone articles published in the long history of EGQSJ. The German Quaternary Association (DEUQUA) presents translations of the originals and critical appraisals of their impact in tandem anniversary issues of DEUQUASP and EGQSJ, respectively.

Original article: https://doi.org/10.3285/eg.28.1.01

Translation: https://doi.org/10.5194/deuquasp-3125-2021

\section{Introduction}

The Lower Rhine Embayment (LRE, or Lower Rhine Basin) has been an area of subsidence since early in the Tertiary. It therefore preserves one of the most complete records of Neogene and Quaternary terrigenous and shallow marine deposits in western Europe. Throughout this period the region's evolution has been controlled by its being underlain by a complex network of tectonically active south-east- to northwest-orientated faults which give rise to horst, graben, and tilted block structures which have imposed a distinctive control on the subsidence history. The south-eastern part of the Netherlands forms the continuation of the LRE which effectively represents the maximum south-easterly extension of the North Sea basin. To the south the LRE is bounded by the Palaeozoic rocks of the Rhenish Massif, the area forming part of the continent-wide European Rift System (e.g. Ziegler, 1994; Van Balen et al., 2005).

For over a century the exploitation of clay in the Netherlands-Germany border area in the west to northwestern part of the basin and extensive open-cast brown-coal mining in the southern part of the region since the mid-20th century (e.g. Boenigk, 1978; Schäfer et al., 2004, 2005) have provided substantial, often spectacular exposures that have been, and continue to be, the focus of extensive research. Boenigk's (1978) article presents a significant milestone summary of thorough investigations in this basin, based on extensive field work and "sedimentological and sedimentarypetrographical" (i.e. gravel petrographical and heavy mineralogical) analyses, supported by palynological research and palaeomagnetism. His results provide a concise systematic summary of the state of knowledge of the geological history of the region through the late Cenozoic in the late 1970s. The general results of this paper have stood the test of time, having been modified only marginally due to more recent investigations. Despite being based upon what some might consider to be a "standard" systematic approach to regional geological and palaeogeographical reconstruction, it is fundamentally central to the understanding of evidence, and moreover, it remains the foundation upon which modern geological investigations continue to be based. 
Seen from the perspective of 40 years later, Boenigk's (1978) article is still a significant contribution which laid the foundation for all subsequent investigations in the LRE, but inevitably research has continued since. Indeed, Boenigk himself published later summaries that further refined and elaborated his own 1978 framework (e.g. Boenigk, 2002; Boenigk and Frechen, 2006), although latterly it has fallen to others to build on his foundations. In particular the extensive work of Westerhoff (2009) and Westerhoff et al. (2008) in the border area and the north-western extension of the LRE to the Roer Valley Graben (RVG) structure beneath the southern Netherlands, together with Kemna $(2005,2008)$ and Schäfer et al. (2004) among others, has provided further insights into the chronology and evolution of the Rhine system in this critical region.

\section{The Rhine sequence in the Lower Rhine Embayment (LRE)}

In principle, the sequence described in Boenigk's (1978) classic paper outlines the development of the region from the latest Oligocene to the Middle Pleistocene, a period characterized by the complex interplay of tectonic activity, climatic variations, marine transgression-regression cycles, and the resulting depositional and erosional responses, each of which operated at different rates. As he says, following the high sea level of the Oligocene when the LRE was flooded by the North Sea, the early Miocene saw the sea regress towards the west and north-west, it being replaced by fluviolacustrine deposition. The latter resulted from local drainage flowing from bounding upland areas, especially the Rhenish Massif to the south and south-west and latterly from the Belgian area to the west. This deltaic sedimentation, favoured by local subsidence, broadly represents an alternating sequence of lignite which interdigitated with fluvial sands, in part derived from the Upper Rhine Graben. These freshwater and marine deposits reflect short-term oscillating sea level superimposed on long-term basinal subsidence. Climatic changes during this interval also alternated from semi-arid early in the Miocene to subtropical and tropical, the latter during the formation of the main lignite. Episodically, the Rhine river drained an area extending southwards into the Upper Rhine Graben (URG) during this time slice.

The Rhine developed in a preliminary form in the Middle Miocene so that by the Pliocene it had already evolved considerably. According to Boenigk (1978), the early Pliocene Rhine deposited large quantities of coarse clastics in the Lower Rhine, the materials originating from a pre-weathered provenance area, comprising highly stable minerals and rounded pebbles, mainly of quartz and quartzite being derived predominantly from the Moselle area. These "Hauptkies" or Waubach Gravel sediments are included in the Kieseloolite Formation. At this time, the Rhine was only a local stream in the Rhenish Massif area.
Reinvestigation of the complex sedimentary sequence of the Lower Rhine Embayment area between Köln (Cologne) in Germany and Venlo in the Netherlands, particularly in the application of modern concepts of sedimentation, has refined, but not revised, the reconstructions. The sediment fill of the LRE consists of thick marine strata in the deepest part that were deposited during the Oligocene, Miocene, and Pliocene (Schäfer et al., 2004). Up to $100 \mathrm{~m}$ thick brown coal or lignite seams occur in the southern part of the LRE (Zagwijn and Hager, 1987) as Boenigk (1978) also acknowledged. They interdigitate with the marine deposits. The upper part of the sediment fill consists of fluvial deposits that started to develop on top of the lignite as a result of increased uplift of the surrounding Rhenish Massif. The onset of the fluvial deposition is thought to be of Late Miocene age (Boenigk, 1978; Schäfer et al., 2004), the river environments gradually prograding north-westwards, reaching the southern part of the Netherlands in the course of the Pliocene, following the shifting coastline (Zagwijn, 1974). This process continued into the Early Pleistocene and eventually resulted in a shift of the marine realm far into the present North Sea.

The subsurface tectonic framework of the southern North Sea basin, including the LRE, strongly controlled the deposition during the Quaternary. The Pliocene and Pleistocene saw the fluvial systems in the LRE typified by a low ratio between accommodation space and sediment supply (Schäfer et al., 2004) leading to fluvial sequences adopting a wide, relatively shallow valley form. Establishment of this "braided" fluvial pattern was facilitated by the deteriorated climatic conditions prevailing at the time. Sediment delivery exceeded the available regional accommodation space of the LRE and RVG, causing the majority of the fluvially transported sediment to bypass these areas and to be deposited further northwards in the main marine depocentre of the North Sea basin (Westerhoff et al., 2008; Westerhoff, 2009). Whilst the RVG provided an important sediment trap, at the basin scale it functioned simply as a regional depocentre where gradual lowering of local base-level increased the preservation potential of Lower Pleistocene deposits.

The subsurface structure of the LRE being determined by the predominantly south-east- to north-west-orientated fault pattern, the faults define individual tectonic blocks of which the subsidence rate can vary considerably. The complexity of this block tectonic pattern of subsidence is highlighted by the fact that the easternmost tectonic block on the LRE, the "Köln-Krefelder Scholle", was tilted along a south-westnorth-east trending axis located near the northern margin of the LRE, around the town of Emmerich (Boenigk and Frechen, 2006). This particular tectonic movement has led to the relative uplift of the southern part of the Köln-Krefelder Scholle, causing incision by the Rhine river and related establishment of a terrace staircase over the course of the Pleistocene until the present day there. This terrace flight can be correlated with that of the Middle Rhine Valley within the Rhenish Massif (Boenigk and Frechen, 2006). The hinge 
line of the basin is situated to the south-east in the LRE. The pattern of the hinge line has been identified in regional subsidence models of the Quaternary. Its position possibly shifted basinwards through the last few million years, but it is assumed that the overall pattern can be compared to the present-day situation (Westerhoff et al., 2008).

Within the RVG and Rurscholle the thickness of the preserved depositional sequences increases from south-east to north-west, this implying that subsidence rates increase in the same direction (Van Balen et al., 2005; Westerhoff et al., 2008). The thicknesses of the various lithostratigraphical units in the Rurscholle in Germany and the RVG in the Netherlands have remained generally constant during Pliocene and Early Pleistocene times, while a minor increase has been recognized during the Middle and Late Pleistocene (Van Balen et al., 2005).

A thorough review, based on standard lithostratigraphy, supported by heavy-mineral analyses from key exposures, has demonstrated that the classic Plio-Pleistocene sequence proposed by previous authors, particularly by Zagwijn (1960) and others, required modification (Westerhoff et al., 2008). This modification has become apparent partially as a result of the reassessment of the Netherlands' lithostratigraphical scheme in which two new formations were recently proposed to replace existing terms. The marked change in provenance of the Late Pliocene Rhine (Boenigk, 2002) has indicated a distinction between a preRhine (Kieseloolite Formation) and the Alpine-connected Rhine system (Waalre Formation). Deposits of the northand north-eastward-draining Belgian rivers (Stramproy Formation) can also be well-recognized before their confluence with the Rhine fluvial system sequences.

Some time before the beginning of the Middle Pleistocene, climatic deterioration combined with increased uplift of the Rhenish Massif (Meyer and Stets, 2002) accounted for deposition of the so-called "Hauptterrassen" or main terrace sequence in the LRE (Boenigk and Frechen, 2006). These cold-climatic, mainly coarse deposits are found throughout the entire LRE. Downstream, in the Netherlands, the Sterksel Formation of the Dutch lithostratigraphy is correlated with the main terrace deposits.

The question of chronology on the LRE sequences is of central importance. At Boenigk's (1978) time, apart from the independent palaeontological and heavy-mineral evidence, there were only two main marker horizons in the record of Late Pliocene and Early Pleistocene fluvial deposits that provide some time control. The lowermost marker horizon represents the first occurrence of Alpine material in the region, expressed by the substantial increase in unstable heavy minerals at the base of the Oebel Beds (Waalre Formation: Boenigk, 2002; Boenigk and Frechen, 2006; Westerhoff et al., 2008). This change was due to the extension of the Rhine's drainage area to the southern URG, with an antecedent course through the Rhenish Massif. Palaeomagnetic measurements from both the Oebel Beds and the underlying
Kieseloolite Formation Reuver Clay demonstrate that these deposits, being normally magnetized, fall within the Gauss Epoch (Kemna, 2005, 2008). They are therefore of Late Pliocene age, a conclusion that corresponds with the available palaeontological evidence (e.g. Zagwijn, 1960, 1974, 1989; Boenigk and Frechen, 2006). The second time control, at the beginning of the Middle Pleistocene, is represented by the Brunhes-Matuyama magnetic reversal that was identified in the deposits "towards the end of the Hauptterrassen phase" (HT III), as Boenigk (1978) mentions.

\section{Implications}

The marked increase in sedimentation that occurred in the latest Cenozoic (e.g. Boenigk, 1978; Westerhoff et al., 2008) reflects the substantial climatic deterioration that characterized the later Pliocene and the beginning of the Quaternary, with glaciation extending to sea level and periglacial frostdominated climates becoming established across Europe. As already mentioned, the LRE preserves the longest and oldest of the fluvial sequences and terrace flights in Europe. Initial deposition of the Kieseloolite Formation in the middle to late Pliocene represents the first of three major depositional events in the LRE. This represents a "mega-fan"-like accumulation of material derived from pre-weathered quartz regolith that resulted from the initial response to climatic deterioration to cold conditions, combined with uplift of the Rhenish Massif. The quartz regolith inherited from the humid Neogene climates phases formed by chemical weathering under dense vegetation cover.

This is followed at the beginning of the Quaternary by deposition of the Waalre Formation, a sequence of relatively fine-grained deposits, laid down under varied climates by the rivers flowing under a predominantly meandering/anastomosing regime. Like the Kieseloolite Formation, these deposits occupy a wide, shallow valley topography, related to the subdued relief. The warm-climate events are of interglacial character with diverse forest vegetation, whilst the colder phases include evidence for frostdominated periglacial conditions (e.g. Zagwijn, 1960).

The third broad division, as Boenigk (1978) notes, is the late Early-Middle Pleistocene main terraces (Hauptterrassen), which represent a second mega-fan-like accumulation, aided by increased rate of tectonic uplift (Meyer and Stets, 2002). The downstream equivalent of the later Hauptterrassen and earliest middle terraces comprise coarse sands and gravels of the Sterksel Formation and have a mixed Rhine and Meuse provenance (Van Balen et al., 2005). Upstream of the confluence of these rivers, and to the west of the LRE, pure Meuse deposits are found ("East-Maas"), which Boenigk and Frechen (2006) referred to as the "Holzweiler Formation". Deposits which can be assigned to the EastMaas according to their sediment-petrography have been identified within the south-western LRE from the Pliocene 
to late Early Pleistocene (Boenigk, 1978; Westerhoff et al., 2008). Although downstream of the confluence the Hauptterrassen do contain some rare Meuse-derived pebbles, this material is potentially reworked from the Holzweiler deposits. The Hauptterrassen are certainly cold-climate accumulations that were deposited by the river adopting a braided pattern. They broadly relate to the late Early Pleistocene to early Middle Pleistocene.

By the time of the formation of the Middle Pleistocene Mittelterrassen (middle terraces), Boenigk (1978) notes that the Rhine had left the western part of the LRE as a consequence of local tectonic movement, migrating to the east of the Ville Block, the move being accompanied by the markedly increased incision of the river's valley. This incision has continued to the present day.

From the Middle Pleistocene, the somewhat better-dated sequences preserved in the LRE overwhelmingly comprise sediments of gravel and sand of braided river, cold-climate origin that began with the Hauptterrassen. This contrast with the Neogene strongly suggests that enhanced fluvial activity was a result of the occurrence of cold climates and the supply of abundant fresh materials by periglacial slope processes, intensified during the Middle Pleistocene transition (1.2-0.8 Ma).

Whilst the processes of valley incision are complex and affected by such factors as flow regime, bed material load, gradient and bedrock exposure, and erodibility, these were also positively affected during cold-climate episodes after this transition. Apparently, climate was at least as significant as tectonic uplift (in the Rhenish Massif), and complex, blocktectonic movement (in the LRE) acted as a primary driver of fluvial incision in the Pleistocene Rhine system (cf. Gibbard and Lewin, 2008). These authors have shown that the evidence corresponds to that of low-relief land surfaces that dominated much of Europe until the Pleistocene. However, in contrast, the younger Middle and Late Pleistocene middle and lower terraces of the Rhine system occur as narrow deposit spreads within a deeply incised valley (e.g. Meyer and Stets, 2002) that was determined by the interplay of "fluvial activity" and tectonics. The change from shallow to deep incision is also reflected in the calibre of the sediment in transport which increases dramatically during the Middle Pleistocene and broadly corresponds to the Middle Pleistocene Transition.

Finally, what is striking to the modern reader is that Boenigk's (1978) review was compiled before the widespread adoption of the marine (oxygen) isotope chronology by terrestrial workers to provide a stratigraphical framework. Despite this it is evident that Boenigk was fully aware of the implications of climate cyclicity to the LRE sequences and the Rhine drainage evolution. Until the recognition of the implications of the marine isotope succession in the early 1970s, terrestrial evidence formed the foundation for the division of Quaternary time. Today the contrast could not be greater, with many abandoning the firmly founded terres- trial chronostratigraphical classification in favour of the lessprecisely defined ocean-floor isotope stratigraphy to provide a foundation for the division of events. Whilst undoubtedly the isotope and ice-core sequences offer a reliable framework, it is important to emphasize that these sequences, especially those in the ocean-bottom sediments, record globalscale changes. This contrasts substantially with terrestrial or shallow marine sequences which preserve locally dominated successions, reflecting local events. Such events are not necessarily represented in the global patterns because the local responses to changes will inevitably lead to modifications to any all-encompassing pattern. For this reason, direct correlation of terrestrial sediment sequences with those in the oceans is a serious matter which should not be undertaken uncritically, and assumed equivalence should be considered critically. Lessons from the past have repeatedly shown that simplistic or mechanistic correlation when examined in detail is unsustainable, Boenigk's (1978) classic article being indisputably a case in point. In essence, Boenigk (1978 and subsequent articles) integrated all his knowledge into a comprehensive picture of the palaeogeographical development and fluvial drainage patterns over time.

Acknowledgements. I thank Frank Preusser for kindly inviting me to prepare this appraisal, and I express my gratitude to Hans Axel Kemna for his generous review and constructive comments that improved the text.

Financial support. The article processing charge was funded by the Quaternary scientific community, as represented by the host institution of EGQSJ, the German Quaternary Association (DEUQUA).

Review statement. This paper was edited by Frank Preusser and reviewed by Hans Axel Kemna.

\section{References}

Boenigk, W.: Die flußgeschichtliche Entwicklung der Niederrheinischen Bucht im Jungtertiär und Altquartär., E\&G Quaternary Sci. J., 28, 1-9, https://doi.org/10.3285/eg.28.1.01, 1978.

Boenigk, W.: The Pleistocene drainage pattern in the Lower Rhine Basin, Neth. J. Geosci., 81, 201-209, 2002.

Boenigk, W. and Frechen, M.: The Pliocene and Quaternary Fluvial Archives of the Rhine System, Quaternary Sci. Rev., 25, 550574, 2006.

Gibbard, P. L. and Lewin, J.: River incision and terrace formation in the late Cenozoic of Europe, Tectonophysics, 474, 41-55, https://doi.org/10.1016/j.tecto.2008.11.017, 2008.

Kemna, H. A.: Pliocene and Lower Pleistocene stratigraphy in the Lower Rhine Embayment, Germany, Kölner Forum, 14, 1-121, 2005 . 
Kemna, H. A.: A revised stratigraphy for the Pliocene and Lower Pleistocene deposits of the Lower Rhine Embayment, Neth. J. Geosci., 87-1, 91-106, 2008.

Meyer, W. and Stets, J.: Pleistocene to recent tectonics in the Rhenish Massif, Neth. J. Geosci., 81, 217-221, 2002.

Schäfer, A., Utescher, T., and Mörs, T.: Stratigraphy of the Cenozoic Lower Rhine Basin, northwestern Germany, Newsl. Stratigraphy, 40, 73-110, 2004.

Schäfer, A., Utescher, T., Klett, M., and Valdivia-Manchego, M.: The Cenozoic Lower Rhine Basin - rifting, sedimentation, and cyclic stratigraphy, Int. J. Earth Sci. (Geol. Rundsch.), 94, 621639, https://doi.org/10.1007/s00531-005-0499-7, 2005.

Van Balen, R. T., Houtgast, R. F., and Cloetingh, S. A. P. L.: Neotectonics of The Netherlands: a review, Quaternary Sci. Rev., 24, 439-454, 2005.

Westerhoff, W.: Stratigraphy and sedimentary evolution. The lower Rhine-Meuse system during the Late Pliocene and Early Pleistocene (southern North Sea Basin), Dissertation, Vrije Universiteit Amsterdam, Amsterdam, the Netherlands, 168 pp., 2009.

Westerhoff, W. E., Kemna, H., and Boenigk, W.: The confluence area of Rhine, Meuse, and Belgian rivers: Late Pliocene and Early Pleistocene fluvial history of the northern Lower Rhine Embayment, Neth. J. Geosci., 87-1, 107-126, 2008.
Zagwijn, W. H.: Aspects of the Pliocene and Early Pleistocene vegetation in the Netherlands, Mededelingen Geologisch Stichting, C3, 78 pp, 1960.

Zagwijn, W. H.: Bemerkungen zur stratigraphischen Gliederung der plio-pleistozänen Schichten des niederländischen-deutschen Grenzgebietes zwischen Venlo und Brüggen, Zeitschrift der Deutschen Geologischen Gesellschaft, 125, 11-16, 1974.

Zagwijn, W. H.: The Netherlands during the Tertiary and Quaternary. A case history of coastal lowland evolution, Geol. Mijnbouw, 68, 107-120, 1989.

Zagwijn, W. H. and Hager, H.: Correlations of continental and marine Neogene deposits in the south eastern Netherlands and the Lower Rhine district. Mededelingen Werkgroep Tertiaire and Kwartaire, Geologie, 24, 59-78, 1987.

Ziegler, P. A.: Cenozoic rift system of western and central Europe. An overview, Geol. Mijnbouw, 73, 99-127, 1994. 